University, but it must have been a great sum, and his muniticence culminated, a few years ago, by his giving and endowing a Clinical Institute, in which good solid work has been going on ever since.

"In short, he was one of the most public-spirited men I ever heard of; and if he had been less distinguished than he was through his many publications, which I suppose you know as well as I do (from 'Meigs and Pepper on Diseases of Children,' onwards), he would be amply entitled to a niche in the Glasgow Medical Journal on account of his position and benefactions as an university man.

"I can also add that among all classes, and in every rank of life, he was alike respected; and if his kindness and generosity to me are any measure of what he was to others of our countrymen, we have all reason to regret the loss of one whose heart was ever inter-national in its sympathies, though profoundly and devotedly patriotic/as regards the great nation from which he sprang."

\title{
ALEXANDER LINISAY, M.D.
}

MANY of our readers will hear with regret of the death of Dr. Alexander Lindsay, for many years occupant of the Chair of Medical Jurisprudence in Anderson's College, Glasgow, which took place at Springbank, Bucklyvie, on Sabbath, 14th August, 1898, at the ripe age of 82 years. Dr. Lindsay was a native of Glasgow, and spent all but the declining years of his life in our City. He received his medical training at the University of Glasgow and at Anderson's College, taking his medical degree in the University in 1845. Two years before this he took the diplorna of the Royal College of Surgeons of Edinburgh. For a considerable time he was assistant to the Professor of Physiology in the University (Dr. Andrew Buchanan), and leaving there was appointed to the Professorship of Forensic Medicine in Anderson's College. The latter post he filled with much success till his retiral in 1887, when he went to reside in Bucklyvie, where one of his sons is a medical practitioner. He had been confined to bed for the past four or five years. Dr. Lindsay was held in high esteem by his professional brethren in the City, and in 1855 he was elected a Fellow of the Faculty of Physicians and Surgeons of Glasgow. He also acted for a time as one of the physicians to the Glasgow Royal Infirmary Dispensary. To many medical men, at present in practice and educated in Glasgow, Dr. Lindsay will be best known as a highly 
successful private teacher, a position for which his great versatility and all-round knowledge peculiarly fitted him. He was buried in the Glasgow High Church Burying-ground.

\section{JAMES PATON, M.D.}

Dr. James Paton, of Greenock, died on 29th August, 1898, at the residence of his brother-in-law, Mr. Douglas, Annfield Road, Liverpool, after an illness extending over six months. $\mathrm{He}$ was first laid aside by severe rheumatic fever, and on a partial recovery he visited Bournemouth for a time, where he improved so much that he ventured home again. His restoration was of brief duration, however, and he then went to reside at Liverpool. A native of Dunfermline, Dr. Paton settled in Greenock in 1870, and built up one of the best practices in that town. He was an acknowledged authority on surgery, his advice and help being often sought in difficult and delicate operations. Dr. Paton, who was 54 years of age, is survived by Mrs. Paton, daughter of the late Captain Galloway.

\section{GURRENT TOPICS.}

Pathology and Bacteriology.-Professor Coats, assisted by Drs. L. R. Sutherland and A. R. Ferguson, will conduct courses of laboratory instruction in bacteriology and practical pathology in the Pathological Institute, Western Infirmary. These commence on Tuesday, 13th September, and continue till Wednesday, 12th October, 1898. They are intended for students of the fifth year as well as graduates. Copies of syllabus may be obtained at the Pathological Institute.

The French Surgical Association.-The Twelfth Congress of this Association will open at Paris, in the Faculty of Medicine, on Monday, 17th October, 1898, under the presidency of Professor Le Dentu, Member of the Academy of Medicine, and surgeon to the Hôpital Necker. The inaugural meeting will be held at 2 o'clock. Two discussions are set down on the programne-(1) On nephrotomy, introduced by MM. Guyon and Albarran; (2) the treatment of goitre (cancer and exophthalmic goitre excepted), introduced by M. J. Reverdin, of Geneva. 